\title{
S ГУМАНИТАРНЫЕ ПРОЕКТЫ
}

P.А. Ханнанов

\section{КОНЦЕПТУАЛЬНЫЕ ОСНОВЫ СИСТЕМНОГО РАЗВИТИЯ TBOРЧЕСТВА: ТЕОРЕТИЧЕСКИЕ ПОДХОДЫ}

\begin{abstract}
Аннотация: В условиях действия вызовов современности человеческий капитал как национальное достояние с его способностью к творческой деятельности приобретает значение мощной движущей силь инновационных преобразований в стране. Однако научные основы проблем творчества не разработаны. Отсутствует системный государственный подход к их решению, основанный на концепции развития творчества в Российской Федерации.

В данной работе автором предлагается своя система взглядов на проблему и её разрешение.

Ключевые слова: Юриспруденциия, экономика, духовность, творчество, человеческий капитал, инновация, эффективность, право, регулирование, концепцчия
\end{abstract}

$\mathrm{H}$ аступивший длительный экономический кризис отрицательно сказался на состоянии творческих возможностей народа, на положении творческого наследия страны. Как следствие этого, возникла особая проблема - создание конкурентоспособной, основанной на интеллекте и знаниях экономики - деятельности, требующей своего решения не за счет ускорения темпов освоения природных ресурсов, а за счет выдвижения и развития идей, изобретений и умения внедрять их в повседневную жизнь ${ }^{1}$, в общественное производство.

Следует отметить, что в основе указанной проблемы лежит комплекс внутренних и внешних факторов, включающий несоответствие нынешней структуры экономики современным требованиям развивающейся страны, сравнительно недопустимый уровень удельного веса образования и науки в общем объеме государственных услуг, обуславливающий неудовлетворительные темпы внедрения генерированных инноваций и их финансовое обеспечение в контексте достижения

\footnotetext{
${ }^{1}$ Президент России / Послание Федеральному Собранию Российской Федерации (официальный сайт). - Москва, Кремль. 2007. 26 апреля. http: // www. kremlin.ru / text/ appears / 2007 / 04 / 25339. shtml. С.3, 8 из 15.
}

эффективных и устойчивых результатов социально экономической деятельности ${ }^{2}$.

Главная причина возникновения и существования указанной проблемы - несистемный подход к творчеству, к государственному и правовому регулированию общественных отношений, составляющих предмет соответствующего воздействия (организационного, экономического, в первую очередь финансового, законодательного).

Устранение данной причины, в условиях ориентации экономики на модернизацию на инновационных началах и принципах, позволит превратить способность к творческой деятельности в обязательный компонент человеческого капитала, сделает ее объектом целенаправленных инвестиций в развитие человека, превратит его в незаменимое звено цивилизованного процесса социально - экономического развития.

С точки зрения науки, творчество - явление реальной действительности, формирующееся в тех или иных конкретно - исторических условиях. В антич-

\footnotetext{
${ }^{2}$ Президент России / Бюджетное послание Президента Российской Федерации Федеральному Собранию Российской Федерации (официальный сайт). - Москва, Кремль.2008.23 июня. http: // www. kremlin.ru / text/ appears / 2008 / 06 / 202940. shtml. С. 1, 6 из 12; путин В.В. О наших экономических задачах. // Ведомости. 2012. 30 января.
} 
ной философии оно первоначально рассматривалось как некое конечное, преходящее и изменчивое бытие, а в дальнейшем как своеобразная устремленность индивида к достижению высшего созерцания мира. В средневековой философии творчество связывалось с божественным началом, вызывающим бытие из небытия. Здесь личное, индивидуальное деяние, есть лишь соучастие в творении мира богом. В эпоху возрождения творчество представляется уже в виде чисто человеческой, продуктивной способности воображения, лежащей в основе познания. По мере развития общества оно становилось наиболее адекватной формой существования. Буржуазная философия придала творчеству прагматизм, инструментализм, неопозитивизм, дух изобретательства, предполагающего решение задачи, подсказанной той или иной ситуацией. И уже в марксистской философии творчество - это деятельность человека, преобразующая мир, реальную действительность в соответствии с целями и осознанными интересами людей на основе объективных законов общества. Оно не только отражает объективный мир, но и создает его.

Творчество, как часть и важная составляющая духовной жизни общества, обладает всеми теми свойствами (или большинством из них), которые присущи материально-духовной природе человека. Оно формируется в ходе приобщения индивида к социальному образу жизнедеятельности.

Отсюда не следует, что в рассматриваемом контексте речь идет о тождестве материального и идеального, а об относительной самостоятельности, автономности идеального мира понятий и образов, об их производности от материальной деятельности и способности материализоваться в самое себя, воплотиться во что-то предметное, об объективации мысли и ее содержания в символы, знаки, изображения, об их взаимной связи и обусловленности. Творческая деятельность принципиально отличается от материальной. Духовные потребности творца, в отличии от материальных, не предопределены биологически. Они возникают и развиваются в процессе воспитания и образования индивида, пребывающего в сфере социального окружения, его участия в создании и освоении духовных ценностей (научных, эстетических и т.п.), в ходе духовного производства. Результатом последнего являются идеи, теории, образы, духовные ценности, духовные общественные связи индивидов, то есть идеальные образования, обладающие всеобщностью потребления, обусловленной всеобщим характером духовного труда, персонифицированностью в силу их идеального и неотделимости от непосредственного производителя, творческой индивидуальностью, самоценностью, нередко проявляющей себя безотносительно к возможному эффекту (итогу).

Творчество, как вид духовного производства, как созидательная деятельность, неповторимо по характеру осуществления и промежуточному результату, отличается оригинальностью, неподдельностью, незаурядностью, своеобразностью и уникальностью, продуктивной активностью человеческого сознания. Именно по указанным качествам в обществе ценится не владелец продуктов духовного труда (вещественного результата), а их производитель или транслятор, что ясно и неоспоримо прослеживается в актах государства - главного заинтересованного в развитии творчества лица, участника духовных общественных связей․․ Судебная

${ }^{3}$ Гражданский кодекс Российской Федерации / Собрание законодательства Российской Федерации. 2006. Ч.ІІ. №52. (В дальнейшем ГК РФ); Федеральный закон от 23 августа 1996 г. №127 - Ф3 «О науке и государственной научно-технической политике» (в ред. Федеральных законов от 19.07.1998. №111 - Ф3, от 17.02.1998. № 189 - Ф3, от 03.01.2000. №41 - Ф3, от 29.12.2000. №168 - Ф3, от 22.08.2004. № 122 - Ф3, от 30.06.2005. № 76 - Ф3, от 31.12.2005. №199-Ф3 с изм., внесенными Федеральными Законами от 27.12.2000. №150 Ф3, от 30.12.2001. №194 - Ф3, от 24.12.2002. №176 - Ф3, от 23.12.2003. №186 - Ф3) / С3 РФ. 1996. №35, Ст. 4137; Постановление Правительства Российской Федерации от 27 июля 1998 г. №844 «О формировании Единого производственнотехнологического комплекса государственных электронных средств массовой информации» (в ред. постановлений Правительства РФ от 27.08.1998. №966, от 22.02.2000. №154, от 08.11.2000. №848, от 22.01.2002. №34, распоряжения Правительства РФ от 23.03.2002. №349 - p, постановления Правительства РФ от 29.05.2002. №364, распоряжения Правительства РФ от 09.09.2002. №1259 - р, постановления Правительства РФ от 26.02.2004. №111) / С3 РФ. 1998. №32. Ст. 3895; распоряжение Правительства РФ от 30.11.2001 г. №1607 - p, «Основные направления реализации государственной политики по вовлечению в хозяйственный оборот результатов научно-технической деятельности» / С3 РФ. 2001. №50. Ст. 4808; совместные (Минэкономики РФ, Минфина РФ, Миннауки и технической политики) «Типовые методические рекомендации по планированию, учету и калькулированию себестоимости научно-технической продукции», утв. 23 мая, 8 , 15 июня 1994 г. / Российские вести. №95. 25.05.1995; Информационное письмо Президиума Высшего арбитражного суда Российской Федерации от 28 сентября 1999 г. №47 «Обзор практики рассмотрения споров, связанных с применением Закона Российской Федерации «Об авторском праве и смежных правах» / Вестник Высшего арбитражного суда Российской Федерации. 1999. №11; решение Верховного суда Российской Федерации от 24 марта 2006 г. № ГКПИ 06-239 (не опублико- 


\section{Политика и общество $10(94) \cdot 2012$}

практика последних лет концентрирует спорные вопросы, связанные с проблемами творческой деятельности, совершением созидательных поступков, в частности, с реализацией авторских и смежных с ними прав, изобретательством и рационализацией, промышленными образцами, полезными моделями, и бескомпромиссно подтверждает такой вывод4.

Права авторов на произведения науки, литературы или искусства независимо от форм, назначения и достоинства произведений, а также способов их воспроизведения (ст. ст. 1248 - 1254, 1301, 1359, ГК РФ), открытия (ст. 1259 ГК РФ), изобретения (ст. 1406 ГК РФ), рационализаторского предложения ${ }^{5}$, промышленного образца, подлежат преимущественной охране перед правами владельцев продуктов духовного труда (ст. ст. 1228, 1406 ГК РФ). Последним такое право может быть предоставлено лишь в случаях выкупа авторского права государством, объявления произведения достоянием государства, принудительного выкупа изобретения государством (ст. 3641 ГК РФ), передачи государству исключительного права на промышленный образец (ст. 1362 ГК РФ). После смерти авторов комплекс прав или его часть, кроме прав на опубликование произведений под своим именем, под условным именем (псевдонимом) или без объявления имени

вано); Постановление Пленума Верховного суда Российской Федерации от 19 июня 2006 г. №15 «О вопросах, возникших у судов при рассмотрении гражданских дел, связанных с применением законодательства об авторском праве и смежных правах» / Бюллетень Верховного суда Российской Федерации. 2006. № 8.

${ }^{4}$ В частности, практика судов изложена в журнале «Изобретатель и рационализатор» за 2006 год: о тождестве технического решения на полезную модель (№1. С. 30); о реализации товаров - клонов путем частичного изменения бренда лицами, не обладающими правом авторства на результаты духовного творчества (№3. С. 30); о контрафактности продукции, не отвечающей формуле изобретения (№2. С. 15); об относимости полезной модели к категории рационализаторского предложения по устройству, т.е. по одному объекту (№3. С. 30); о доказательственном значении инновационной документации на новые изделия и способы производства, разработанные на основе изобретения, содержащего все признаки формулы изобретения или любого ее независимого пункта (№8. С. 27-28); об оплате вознаграждения за результаты интеллектуального творчества (№10. С. 28) и др.

${ }^{5}$ В этой связи не излишне заявить, что категория и «рационализаторское предложение» постепенно и необоснованно выводится из научного оборота заменялась категорией «полезная модель», представляющей узкий вариант такого предложения (рационализаторское предложение по устройству) - Изобретатель и рационализатор. 2006. №3. С. 30. (анонимно) - (ст. 1112 ГК РФ), переходит к их наследникам и подлежит соответствующей их правовому положению защите (охране).

Однако в творчестве духовное органически взаимосвязано с практической деятельностью. Все мыслительные операции человека формируются в процессе своеобразного переноса внешне предметных актов во внутренний, идеальный план. «Предметность» творчества - это его свойство отражать объективные потребности и тенденции развития общества. Объективация конечного результата в виде материального (конечного, вещественного) возводит творчество в ранг сознательного производящего акта ${ }^{6}$. Творить - значит создать нечто новое, раньше вообще не существовавшее ${ }^{7}$, но новое в своем количественном и качественном единстве. «...Самый плохой архитектор, - писал К.Маркс, - от наилучшей пчелы с самого начала отличается тем, что, прежде чем строить ячейку из воска, он уже построил ее в своей голове» ${ }^{8}$.

При этом новизна творчества определяется применительно к конкретному виду творческой деятельности. Так, новизна открытия должна пониматься как обнаружение новой закономерности, свойства или явления материального мира, как познание их сущности, внутренне необходимых связей, качественно отличающихся от других явлений. Изобретение признается новым, если оно неизвестно из достигнутого уровня техники, то есть решение, составляющее его содержание, не следует из достигнутого уровня техники, обладает существенно устойчивыми признаками и свойствами и промышленно применимо. Без последних данный предмет, как овеществленный результат изобретения, перестает быть самим собой. Существенная новизна изобретения есть новизна его сущности ${ }^{9}$. Для рационализаторского предложения достаточно так называ-

\footnotetext{
${ }^{6}$ Воронин Б.А., Ханнанов Р.А., Ханнанова Т.Р. Новые концептуальные основы обеспечения устойчивости аграрного производства. // Аграрный вестник Урала. 2012. №6.

7 Даль В.И. Толковый словарь русского языка. Современная версия.- М.: издательство Эксмо. С.645; Ожегов С. И. Словарь русского языка: Ок.53 слов / С. И. Ожегов; Под ред. Проф. С.И.Скворцова. - 24 изд., испр. - М.: ООО «Издательский дом ОНИКС 21 век»: ООО «Издательство «Мир и Образование», 2004. С. 1035.

${ }^{8}$ Маркс К. и Энгельс Ф. Соч. Т. 23. С. 189.

${ }^{9}$ Ионас В.Я. Изобретательское правоотношение в советском гражданском праве. Автореферат канд. дисс-Л.:1955. С. 8. Антимонов Б.С., Флейшии Е.А. Изобретательское право. M.: 1960. C. $83-84$.
} 
емой местной новизны, то есть неизвестности технического решения предприятию, которому оно подано.

Bсе сказанное говорит о том, что творчество на самоцель. Человеческое общество заинтересовано не в самом по себе процессе творчества, а в том, чтобы оно завершилось достижением определенного полезного результата, могущего в дальнейшем стать основанием получения другого, в частности социального, экономического эффекта ${ }^{10}$. Появление указанного результата завершает процесс духовного производства, состоящего из учета (анализа) практического опыта, просветления, озарения, предвидения, предсказания и создания духовных ценностей, становящихся, в свою очередь, предпосылками материального. Поэтому творчество есть материальный поступок. При творении нового, как видно из изложенного, совершаются практические действия, в которых у лица может и не быть намерения стать участником соответствующих гражданских правоотношений. Так, деятельность приводящая к открытиям, созданию произведений науки, литературы, искусства, изобретений, рационализаторских предложений, полезных моделей, промышленных образцов, топологии интегральных микросхем, программ и других объектов, являющихся конкретными формами творческих поступков, осуществляется вне зависимости от возможных правовых последствий. Здесь важен сам объективированный результат. «При этом совершенно не существенно, имел ли ввиду автор приобрести...право или нет»,- писал М.М. Агарков ${ }^{11}$.

Материальность творчества, направленность его на социально-экономический результат, обуславливает необходимость государственного вмешательства в процесс создания нового. Конкретно такое вмешательство выражается в планировании и финансировании творческой деятельности, в ориентировании на сосредоточение вокруг задач, в разрешении которых общество испытывает потребность. После того, как будет создан продукт творческого труда, возникают отношения между государством и творцом по поводу использования продукта в интересах всех членов общества. Разумеется, указанные отношения требуют известного упорядочения и правового регулирования.

Отношения, порожденные творческой деятельностью, впоследствии ставшие предметом правового опосредования, обобщенно можно назвать отношени-

\footnotetext{
${ }^{10}$ Воронин Б.А., Ханнанов Р.А., Ханнанова Т.Р. Указ. работа.

${ }^{11}$ Агарков М.М. Учение о ценных бумагах. - М.: 1927. С. 96.
}

ями по поводу присвоения творчества. Рассматриваемые общественные отношения можно разделить на два подвида: на отношения по экономическому присвоению творчества и на отношения авторства, т.е. духовного присвоения.

Для бизнеса важно, главным образом, экономическое присвоение творчества. Поэтому государство стимулирует развитие отношений, в которых результаты творческой деятельности выступают как потребительская ценность. Юридическим средством такого стимулирования является установление права использования продуктов творчества (произведений науки, изобретений и рационализаторских предложений, а также открытий и т.п.), причем, наделение не только творцов, но и самих хозяйствующих субъектов правом осуществлять творческую деятельность и одновременно возложение обязанности использовать ее результаты. Юридические основы творческой деятельности были заложены еще Положением об открытиях, изобретениях и рационализаторских предложениях, утвержденным постановлением Совета Министров СССР от 21 августа 1973 года №584 ${ }^{12}$.

В соответствии с ним регламентировались организационные, имущественные, личные неимущественные и трудовые отношения, возникающие в связи с открытиями, изобретениями и рационализаторскими предложениями.

В настоящее время, как и ранее, открытием признается установление неизвестных ранее объективно существующих закономерностей, свойств и явлений материального мира, вносящих коренные изменения в уровень познания.

Изобретение - новое и обладающее существенными отличиями техническое решение в любой области, относящееся к продукту или способу (процессу осуществления действий над материальным объектом с помощью материальных средств - (ст. 1350 ГК РФ)). В отличие от открытий, к числу которых относятся научные положения, представляющие собой решения познавательной задачи, изобретения являются техническими решениями проблематичной для субъектов задачи.

Рационализаторским предложением признавалось техническое решение, являющееся полезным для предприятия, организации или учреждения, которому оно подано, и предусматривающее изменение кон-

\footnotetext{
${ }^{12}$ Открытия, изобретения и рационализаторские предложения (нормативные акты). - М.: ЦНИИПИ, 1974. С. 5. В дальнейшем Положение.
} 


\section{Политика и общество $10(94) \cdot 2012$}

струкций изделий, технологии производства и применяемой техники или изменения состава материала.

Значение открытий определяется тем, что в современных условиях достижения науки должны быть использованы в интересах роста валового внутреннего продукта, создания новых производственных мощностей, увеличения производительности и качестве труда, повышения престижа научно-технической деятельности, то есть развития производительных сил и подъема экономики страны. Социально - экономическое развитие требует внесения определенности в достоверность результатов научных исследований. В противном случае могут быть произведены огромные затраты на попытки практического использования результатов исследований, которые оказались ложными. Кроме того, это может тормозить внедрение инноваций, так как усилия будут сосредоточены в неправильном направлении.

Органическим элементом научно-технического прогресса является изобретательство, рационализация, создание промышленных образцов, полезных моделей и других объектов творчества. Государство уделяет определенное внимание развитию последних. В этих целях оно возлагает отдельные задачи и на органы управления от министерств до руководителей структурных и других предприятий. Названные органы в процессе своей деятельности обязаны: 1) создать условия для максимально быстрого и широкого использования каждого изобретения и рационализаторского предложения и промышленного образца и т.п.; 2) обеспечить мобилизацию творческой активности работающих на совершенствование применяемой техники путем использования принципа морального и материального стимулирования. Исходя из этих задач должно осуществляться правовое регулирование отношений, возникающих в связи с изобретениями и рационализаторскими предложениями. Способность к творческой деятельности должна рассматриваться как новая составляющая человеческого капитала, влекущая за собой правовые последствия в виде связанности для участников общественных отношений.

Создание условий для быстрого и широкого использования в хозяйственной деятельности результатов творческого труда предполагает соответствующее оформление авторства на открытие, изобретение, рационализаторское предложение, промышленный образец (ст. 1377 ГК РФ) и полезную модель (ст. 1353 ГК РФ). Оформление авторства на указанные виды творческой деятельности имеет важное государственное значение.
Этим обеспечивается правовая охрана обнаруженных или полученных новшеств, закрепляется приоритет государства на открытия, исключается возможность безвозмездного использования изобретений за границей и незаконного присвоения авторства на то или иное новшество, достигается сохранение тайн секретных открытий и изобретений и, самое главное, открываются возможности к развитию и внедрению инноваций в производство.

Авторство на открытия, изобретения и рационализаторские предложения охраняется законом и удостоверяется документами.

Внедрение научных и технических новшеств в производство - конечное звено в творческой деятельности, имеющее огромное общегосударственное значение. На этой стадии окончательно выявляется степень решения основной цели творческого процесса, их экономический и иной положительный эффект как показателя эффективности использования человеческого капитала.

Действующее законодательство поощряло и поощряет внедрение научных и технических новшеств в производство, рассматривая это как одну из юридических обязанностей государственных и кооперативных предприятий (организаций), соответствующих министерств и ведомств. В постановлениях Правительства РФ внимание органов хозяйственного управления обращается на необходимость создания наиболее благоприятных условий для дальнейшего развития инновационной деятельности ${ }^{13}$, изобретательства, других

\footnotetext{
${ }^{13}$ Основы политики Российской Федерации в области науки и технологий на период до 2010 года и дальнейшую перспективу, утв. Президентом Российской Федерации 30 марта 2002 г. ПР-576, опубликованные Минобразования и науки РФ // http // mon.gov.ru / dok / ukaz / nti / 4431 /; Ф3 Российской Федерации от 20 июля 2011 г. №249-Ф3 «О внесении изменений в Федеральный закон «О науке и государственной научно-технической политике» и ст. 251 части второй Налогового Кодекса Российской Федерации в части уточнения правового статуса фондов поддержки научной, научнотехнической и инновационной деятельности)». // Российская газета. 2011. 26 июля и 28 июля 2012 г. №135-Ф3 «О внесении изменения в ст. 15.1 Федерального закона «О науке и государственной научно-технической политике». // СЗ РФ. 2012. №31. Ст. 4324; постановление Правительства РФ от 20 декабря 2011 г. №1035 «О внесении изменений в Федеральную целевую программу «Исследования и разработки по приоритетным направлениям развития научно-технического комплекса России на 2007-2013 годы». // С3 РФ. 2012. №1. Ст. 94; Концепция долгосрочного социально-экономического развития Российской Федерации на период до 2020 года. Раздел І. Подраздел II // С3 РФ. 2008. №47. Ст. 5489.
} 
видов и форм технического творчества на предприятиях, упорядочения внедрения их результатов и предложений в производство, материального стимулирования их авторов.

Указанные органы обязаны разрабатывать перспективные и текущие тематические прогнозы по изобретательству, в целом по техническому творчеству. Однако они рассматривают предложения рационализаторов, внедряют изобретения и предложения в производство по своему усмотрению и в условиях отсутствия действенного общегосударственного (общеотраслевого) контроля и вмешательства, бессистемно и не всегда на прогностических началах, без должного соучастия в этом важном для экономики страны государства, бизнеса и гражданского общества, без учета современных реалий, современных вызовов, задач, обусловленных вступлением России в ВТО и др.

В дальнейшем совершенствовании нуждается также вся система научно-технической информации. В ее организационном построении и осуществлении деятельности немало недостатков.

В интересах повышения творческой активности работающих целесообразно внести в законодательство об интеллектуальной деятельности и средствах индивидуализации соответствующие изменения.

Творчество - неотъемлемый атрибут всего человечества. Оно присутствует во всех сферах деятельности людей и поэтому относится к категории глобального, а в рамках отдельных национальных государственных образований, - к категории народного (национального), требующего за собой системного, целостно-единого, структурно-согласованного подхода. Как явление реальной действительности, обладающее свойством объективности, творчество, прежде всего нуждается в осознании в контексте связей объективного и субъективного, материального и идеального, предметного и духовного. В условиях организации народонаселения планеты во всемирное содружество (сосуществование) творческая деятельность не может не строиться на принципах всеобщности и взаимности бытия и взаимопроникновения, обмена, целесообразности, гуманности, социально-экономической выгодности. Именно в этих целях и принципах предпринимаются масштабные и значительные усилия мирового содружества государств по устойчивому развитию, охране природы и энергоресурсов земли, освоению космоса и мирового океана, глобализации науки, делаются открытия всемирного масштаба, разрабатываются соответствующие этим усилиям концепции и теории (концепции: дрейфа материков, неосферы, Большого взрыва, приоритета норм международного права; теории: общей и специальной относительности, соотношение неопределённостей, иммунитета, квантовая теория строения вещества, диссипативных систем, электрослабового взаимодействия, высокотемпературной сверхпроводимости, сверхпластичности металлов, мирного сосуществования различных социально-экономических систем и др.), нашедшие своё всемирное признание.

Национально-государственный аспект проблемы творчества должен строиться, прежде всего, на этих же принципах и концептуальных подходах к его бытию и осуществлению. Однако в России и тем более в её регионах нет единого подхода к государственно-правовому регулированию творческих связей как одной из разновидностей духовных общественных отношений. Нет общего, пригодного для развития духовного творчества и его отраслей (видов, разновидностей, направлений) национального определения понятий “творчество" и “творческая деятельность”. Философские понятия указанных категорий слишком абстрактны и преподносятся лишь в плане изучения проблем духовного производства. По данной причине обычные, входящие в содержание деятельности (работы) специалистов акты поведения, объявляются творческими. Это особенно заметно в искусстве, где любое, порою даже бездарное, некачественное исполнение какого-нибудь произведения, преподносится в качестве творчества, а его исполнителя - творческими работниками. В научной деятельности, например, любое, по существу справочное обобщение, завершаемое соответствующим заключением трудового квалификационного характера, объявляется научным, а лицо (специалист) его выполняющий - научным сотрудником, учёным. И это несмотря на то, что в первом случае, как и во втором, нет творческого характера труда исполнителя и его деятельность носит нетворческий несовместимый с законом характер (ст. 1228 ГК РФ).

Неразработанность научных основ проблем творчества и игнорирование норм действующего законодательства, регулирующего творческие связи, формируют ситуацию семейственности и неоправданного протекционизма в сфере творчества и порождают армию лиц «при искусстве» и «при науке».

Разработка научных основ проблемы творчества, прежде всего философских и социальных, создало бы почву для дальнейшего развития творческой деятельности, определения её системы и структуры (составляющих): (народное творчество (фольклор), искус- 


\section{Политика и общество $10(94) \cdot 2012$}

ство, наука и др.), взаимосвязи между их элементами, существенные и закономерные стороны, достойные признания и восприятия в формах государственного и правового регулирования. Например, такое составляющее творческой деятельности, как наука, могло быть представлено не только как социальное составляющее общества, но и прежде всего как самый значимый элемент духовного производства, обладающий своей структурой (фундаментальная наука и прикладная наука, а в рамках последних - общественные и естественные науки, в свою очередь, общественные с подразделением на философские, социологические, исторические, экономические и т.д., естественные - о природе, космосе, вселенной и т.д.). Это позволило бы установить между отраслями и подотраслями науки корреляционные и иные внутренние связи, их упорядочение в интересах людей, общества и государства, управлять научным сообществом и исследованиями, принимать по ним профессиональные решения, исключить некомпетентное вмешательство в научную деятельность, сократить и рационально использовать ассигнования на науку и т.д., в конечном счёте, сделать шаг в первую очередь в сторону инновационной деятельности, в направлении превращения науки в производительную силу общества. В настоящее время научная деятельность в стране непростительно слабо прогнозируется и регламентируется. Научные исследования отстают от потребностей практики, не опережают, а лишь сопровождают их. По этой причине низка их результативность. Пример тому - навязанная в волевом порядке реформа экономики, которая лишь способствовала развитию и углублению общего.

Творческие коллективы предоставлены самим себе, их работа и усилия не координируются и не направляются по единому руслу научных исследований, должным образом не стимулируются. В науке царствует мелкотемье, сопровождаемое незначительной отдачей.

Государство в значительной мере отвернулось от науки и не принимает достаточных мер к восстановлению её потенциала, нет действенного контроля с его стороны за аттестацией научных кадров. Широкое распространение получила практика разработки проблем тем диссертаций и подготовки диссертаций к защите, и, даже организация и защита диссертаций научными руководителями за приличную «мзду», остепенение «соискателей», абсолютно далеких от научных проблем, но занимающих высокие должности.

Отдельные правовые акты государства, рассчитанные на обеспечение нормальной научной деятельно- сти, носят частный и ограниченный характер, охватывающий какой-то один клубок проблемы научного обеспечения страны.

Всё это, опять же, результат бессистемного подхода к научной творческой деятельности, к организации науки, к её поистине колоссальным результатам и достижениям ${ }^{14}$.

Выход из создавшегося положения видится в отходе от упрощённого понимания научного творчества, игнорирования его сложного, системного, структурно - управляемого, развивающегося формирования.

Как указывалось выше, творческая деятельность представляет собой процесс духовного производства, состоящий из двух этапов: использование человеческого капитала, воспроизводства идей, образов, представлений, понятий, догм и т.п. посредством анализа практического опыта, просветления, озарения, предвидения, предсказания, совершения других аналогичных актов поведения, т.е. создания духовных ценностей (идеальный этап) и перехода духовных ценностей в разряд социально-экономического результатов, оцениваемых (характеризуемых) показателями с двуединым содержанием (духовная потребность, духовная деятельность, духовные блага, удовлетворение духовных потребностей, духовный и социально - экономический результат и т.д.).

Первый этап процесса охватывает производство сознания личностью, коллективами, профессионально занятыми квалифицированным умственным трудом, недоступным для большинства. Он, по своей природе, творчески индивидуален, психофизичен и в условиях господства свободы личностей, свободы научного творчества (п.3 ст. 7 Закона о науке и государственно научно - технической политике) не принуждён, но поощряем. Государство может только стимулировать развитие данного процесса соответствующим его природе правовым регулированием, установлением правовых норм, предусматривающих меры морального и материального характера для творцов, предоставлением льгот и преимуществ и иных мер персонального воздействия на физических и юридических лиц. Принуждения к участию в творческом процессе на этом

14 Постановление Правительства Российской Федерации от 18 ноября 2006 г. № 696 “Об осуществлении контроля в сфере правовой охраны и использования результатов научно - исследовательских, опытно - конструкторских и технологических работ гражданского назначения, выполняемых за счёт средств федерального бюджета" и одноимённое Положение (С3 РФ. 2006. №48. Ст. 5027). 
этапе духовного производства неоправданны и нецелесообразны, т. к. они могут завершаться отрицательным результатом. Это - во первых.

Следует отметить, что данный этап, точнее даже направление духовного творчества, остро нуждается в особом внимании со стороны государства, в «крышевании», в разработке особой системы поиска талантов, целенаправленного формирования когорты одаренных людей, утверждения правил, исключающих и вытесняющих из неё бездарей, приспосабливающихся к науке, «прилипал». В последнее время их стало очень много. Именно они «съедают» значительную часть выделяемых ассигнований на науку, тем самым отбивая желание способных личностей заниматься сулящими высокую отдачу от научных исследований. В этой связи уместно отметить и то, что в сфере научного творчества в пореформенный период обнаружилась нездоровая тенденция гиперболизации значимости молодежной науки в ущерб интересам мобилизации научных достижений старшего поколения ученых. Почти повсеместно научные форумы (конференции, встречи, семинары и т.д. и т.п.) проводятся под эгидой активизации научно ориентированной молодежи, чем по существу изживаются из науки заслуженные, имеющие значительные заслуги в науке, деятели пожилого возраста. Они, таким образом, выставляются на второй план научного творчества. Вместе с ними уходят в забытье их исследовательский опыт, предвидение насущных проблем современности, фундаментальный настрой их разрешения, на смену им приходит низкая отдача от науки, а то и вовсе такая отдача исключается, не достигается.

Наука должна стать плодородным полем деятельности всех талантливых ученых страны, независимо от их возраста. Иное понимание проблемы грозит свертыванием самой науки, её поистине колоссальных результатов.

Во-вторых. В отличие от первого этапа на втором этапе духовного производства его продукты материализуются, воплощаются во что-то предметное (символы, знаки, изображения, звуки и т.д.), способные удовлетворять социальные или экономические интересы общества, государства, личности. Объективация предметного, обособление его смысла и содержания от отдельных индивидов создаёт условия для их присвоения и освоения, приобщения к ним заинтересованных в их использовании лиц, прежде всего государства. Отношения, возникающие на втором этапе духовного производства, в силу их общеполезности могут и должны подвергаться государственному и правовому регулированию. Положительный пример тому - проводимые в стране программно - прогностические мероприятия творческого характера, направленные на получение, применение научных знаний для решения технологических, инженерных, экономических, социальных, гуманитарных и иных проблем, обеспечения функционирования науки, техники и производства как единой системы (ч. 2 ст. 2 Федеральный закон о науке и государственной научно - технической политике; Разделы I и II - Федеральной целевой программы «Исследования и разработки по приоритетным направлениям развития научно - технологического комплекса России на 2007 - 2013 годы», утвержденной постановлением Правительства РФ от 17 октября 2006 года ${ }^{15}$ ), и на вовлечение в хозяйственный оборот результатов научно - технологической деятельности (п. 1 Распоряжения Правительства Российской Федерации от 30 ноября 2001 г. №1607-р) ${ }^{16}$.

Творчество - не только неотъемлемый, но и общий атрибут всех сфер жизнедеятельности человека. В таком качестве, т.е. в целостном, едином, комплексном, всеохватывающем варианте, оно является объектом изучения и познания разнообразными общественными, государственными, хозяйственными структурами, ожидающими от него общеполезные последствия. Несмотря на это, своего системного взгляда на себя как на явление реальной действительности оно не имеет.

Чем, например, объяснить тот факт, когда творчество до сего времени не нашло своего официального и легализованного признания со стороны государства в качестве национального достояния России. Практикуемый в стране конкурсный порядок разработки и реализации достижений науки чреват негативными последствиями. Действующие ныне формы вознаграждения разработчиков-исследователей типа грантов, премий, президентских и правительственных стипендий, присуждения работам бесплатных лауреатских наименований и т.д. по большому счету не стимулируют развития системных научных исследований и не работают на укрепление экономики и социальной сферы, постепенно сводятся на нет. Более того под видом уплаты самих этих вознаграждений творчество, как национальное достояние страны, большей частью уходит зарубеж, работать на удовлетворение интересов других стран. И это будет продолжаться до

\footnotetext{
${ }^{15}$ СЗ РФ. 2006 . № 44. Ст. 4589.

${ }^{16}$ СЗ РФ. 2001 . № 50. Ст. 4808.
} 


\section{Политика и общество 10 (94) • 2012}

тех пор, пока не будет установлен правовой режим реализации научных исследований, выполняемых и выполненных по конкурсу, защищающий интересы отечества в приоритетном порядке.

Творчество, к сожалению, пока еще не стало предметом концептуального рассмотрения, что мешает разработке по нему общего замысла в рамках общегосударственного масштаба.

На наш взгляд, разработка концепции развития творчества в Российской Федерации - задача уже давно назревшая, ибо отсутствие ее сдерживает выход страны на мировой уровень духовного и связанного с ним инновационного общественного производства. Современная экономика и политика без творческого скачка, прорыва, внедрения достижений, носящих творческий характер, уже абсолютно немыслимы.

Предлагаемая концепция представляется в виде легально признанного и общегосударственного документа. Концепция должна опираться на соответствующий закон о развитии творчества в стране и на одноименную Федеральную программу, содержать анализ состояния творческих отношений, очертить проблемы в этой сфере, четко и ясно выработать институциональные понятия творчества и творческих отношений, а также связанных с ними понятий, цели, основные задачи будущей программы, направления и условия перехода к комплексному развитию творчества в федеральном и региональным аспектах, критерии принятия решений, показатели и индикаторы, сроки и этапы реализации программы, объем и источники финансирования последней, ожидаемые конечные результаты претворения ее в жизнь и показатели социальноэкономической эффективности.

\section{Библиография:}

1. Президент России / Послание Федеральному Собранию Российской Федерации (официальный сайт). - Москва, Кремль. 2007. 26 апреля. http: // www. kremlin.ru / text/ appears / 2007 / 04 / 25339. shtml. С.3, 8 из 15.

2. Президент России / Бюджетное послание Президента Российской Федерации Федеральному Собранию Российской Федерации (официальный сайт). - Москва, Кремль. 2008. 23 июня. http: // www. kremlin.ru / text/ appears / 2008 / 06 / 202940. shtml. С. 1, 6 из 12; Путин В.В. О наших экономических задачах. // Ведомости. 2012. 30 января.

3. Гражданский кодекс Российской Федерации / Coбрание законодательства Российской Федерации. 2006. Ч. II. №52. (В дальнейшем ГК РФ).

4. Федеральный закон от 23 августа 1996 г. №127 - Ф3 «О науке и государственной научно-технической политике» (в ред. Федеральных законов от 19.07.1998. №111 - Ф3, от 17.02.1998. № 189 - Ф3, от 03.01.2000. №41 Ф3, от 29.12.2000. №168 - Ф3, от 22.08.2004. № 122 - Ф3, от 30.06.2005. №76 - Ф3, от 31.12.2005. №199-Ф3 с изм., внесенными Федеральными Законами от 27.12.2000. №150 Ф3, от 30.12.2001. №194 - Ф3, от 24.12.2002. №176 - Ф3, от 23.12.2003. №186 - Ф3) / C3 РФ. 1996. №35, Ст. 4137.

5. Федеральный закон Российской Федерации от 20 июля 2011 г. №249-Ф3 «О внесении изменений в Федеральный закон «О науке и государственной научно-технической политике» и ст. 251 части второй Налогового Кодекса Российской Федерации в части уточнения правового статуса фондов поддержки научной, научнотехнической и инновационной деятельности)». // Российская газета. 2011. 26 июля и 28 июля 2012 г. №135-Ф3 «О внесении изменения в ст. 15.1 Федерального закона «О науке и государственной научно-технической политике». // C3 РФ. 2012. №31. Ст. 4324.

6. Основы политики Российской Федерации в области науки и технологий на период до 2010 года и дальнейшую перспективу, утв. Президентом Российской Федерации 30 марта 2002 г. ПР-576, опубликованные Минобразования и науки РФ // http // mon.gov.ru / dok / ukaz / nti / 4431 /.

7. Постановление Правительства Российской Федерации от 27 июля 1998 г. №844 «О формировании Единого производственно-технологического комплекса государственных электронных средств массовой информации» (в ред. постановлений Правительства РФ от 27.08.1998. №966, от 22.02.2000. №154, от 08.11.2000. №848, от 22.01.2002. №34, распоряжения Правительства РФ от 23.03.2002. №349 - p, постановления Правительства РФ от 29.05.2002. №364, распоряжения Правительства РФ от 09.09.2002. №1259 - р, постановления Прави- 
тельства РФ от 26.02.2004. №111) / С3 РФ. 1998. №32. Ст. 3895.

8. Постановление Правительства Российской Федерации от 18 ноября 2006 г. № 696 “Об осуществлении контроля в сфере правовой охраны и использования результатов научно - исследовательских, опытно - конструкторских и технологических работ гражданского назначения, выполняемых за счёт средств федерального бюджета" и одноимённое Положение (С3 РФ. 2006. №48. Ст. 5027).

9. Постановление Правительства РФ от 20 декабря 2011 г. №1035 «О внесении изменений в Федеральную целевую программу «Исследования и разработки по приоритетным направлениям развития научно-технического комплекса России на 2007-2013 годы». // С3 РФ. 2012. №1. Ст. 94.

10. Распоряжение Правительства РФ от 30.11.2001 г. №1607 - p, «Основные направления реализации государственной политики по вовлечению в хозяйственный оборот результатов научно-технической деятельности» / С3 РФ. 2001. №50. Ст. 4808; совместные (Минэкономики РФ, Минфина РФ, Миннауки и технической политики) «Типовые методические рекомендации по планированию, учету и калькулированию себестоимости научно-технической продукции», утв. 23 мая, 8, 15 июня 1994 г. / Российские вести. №95. 25.05.1995.

11. Концепция долгосрочного социально-экономического развития Российской Федерации на период до 2020 года. Раздел I. Подраздел II // С3 РФ. 2008. №47. Ст. 5489.

12. СЗ РФ. 2006. № 44. Ст. 4589.

13. С3 РФ. 2001. № 50. Ст. 4808.

14. Постановление Пленума Верховного суда Российской Федерации от 19 июня 2006 г. №15 «О вопросах, возникших у судов при рассмотрении гражданских дел, связанных с применением законодательства об авторском праве и смежных правах»/ Бюллетень Верховного суда Российской Федерации. 2006. № 8.

15. Информационное письмо Президиума Высшего арбитражного суда Российской Федерации от 28 сентября 1999 г. №47 «Обзор практики рассмотрения споров, связанных с применением Закона Российской Федерации «Об авторском праве и смежных правах»/ Вестник
Высшего арбитражного суда Российской Федерации. 1999. №11; решение Верховного суда Российской Федерации от 24 марта 2006 г. № ГКПИ 06-239 (не опубликовано).

16. Агарков М.М. Учение о ценных бумагах. - М.: 1927. С. 96.

17. Воронин Б.А., Ханнанов Р.А., Ханнанова Т.Р. Новые концептуальные основы обеспечения устойчивости аграрного производства. // Аграрный вестник Урала. 2012. №6.

18. Даль В.И. Толковый словарь русского языка. Современная версия. - М.: издательство Эксмо. С. 645 .

19. Ожегов С. И. Словарь русского языка: Ок.53 слов. / С. И. Ожегов; Под ред. Проф. С.И.Скворцова. - 24 изд., испр. - М.: ООО «Издательский дом ОНИКС 21 век»: ООО «Издательство «Мир и Образование», 2004. С. 1035.

20. Ионас В.Я. Изобретательское правоотношение в советском гражданском праве. Автореферат канд. дисс-Л.: 1955. С. 8.

21. Антимонов Б.С., Флейшиц Е.А. Изобретательское право. - М.: 1960. С. 83-84.

22. Маркс К. и Энгельс Ф. Соч. Т. 23. С. 189.

23. Открытия, изобретения и рационализаторские предложения (нормативные акты). - М.: ЦНИИПИ, 1974. С. 5.

\section{References (transliteration):}

1. Prezident Rossii / Poslanie Federal'nomu Sobraniyu Rossiyskoy Federatsii (ofitsial'nyy sayt). Moskva, Kreml'. 2007. 26 aprelya. http: // www. kremlin.ru / text/ appears / 2007 / 04 / 25339. shtml. S.3, 8 iz 15.

2. Prezident Rossii / Byudzhetnoe poslanie Prezidenta Rossiyskoy Federatsii Federal'nomu Sobraniyu Rossiyskoy Federatsii (ofitsial'nyy sayt). - Moskva, Kreml'. 2008. 23 iyunya. http: // www. kremlin.ru / text/ appears / 2008 / 06 / 202940. shtml. S. 1, 6 iz 12; Putin V.V. O nashikh ekonomicheskikh zadachakh. // Vedomosti. 2012. 30 yanvarya.

3. Agarkov M.M. Uchenie o tsennykh bumagakh. - M.: 1927. S. 96.

4. Voronin B.A., Khannanov R.A., Khannanova T.R. Novye kontseptual'nye osnovy obespecheniya ustoychivosti agrarnogo proizvodstva. // Agrarnyy vestnik Urala. 2012. №6. 


\section{Политика и общество 10 (94) • 2012}

5. Dal' V.I. Tolkovyy slovar' russkogo yazyka. Sovremennaya versiya. - M.: izdatel'stvo Eksmo. S.645.

6. Ozhegov S. I. Slovar' russkogo yazyka: Ok.53 slov. / S. I. Ozhegov; Pod red. Prof. S.I.Skvortsova. - 24 izd., ispr. - M.: OOO «Izdatel'skiy dom ONIKS 21 vek»: OOO «Izdatel'stvo «Mir i Obrazovanie», 2004. S. 1035.
7. Ionas V.Ya. Izobretatel'skoe pravootnoshenie v sovetskom grazhdanskom prave. Avtoreferat kand. diss-L.: 1955. S. 8. 8. Antimonov B.S., Fleyshits E.A. Izobretatel'skoe pravo. - M.: 1960. S. 83-84.

9. Marks K. i Engel's F. Soch. T. 23. S. 189.

10. Otkrytiya, izobreteniya i ratsionalizatorskie predlozheniya (normativnye akty). - M.: TsNIIPI, 1974. S. 5. 